\title{
Variance components using genomic information for 2 functional traits in Italian Simmental cattle: Calving interval and lactation persistency
}

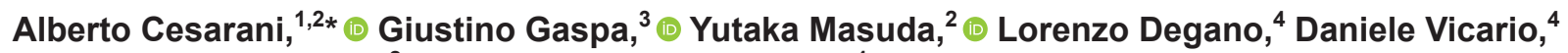 \\ Daniela A. L. Lourenco, ${ }^{2}$ (D) and Nicolò P. P. Macciotta ${ }^{1}$ (D)

\section{ABSTRACT}

Functional traits, such as fertility and lactation persistency, are becoming relevant breeding goals for dairy cattle. Fertility is a key element for herd profitability and animal welfare; in particular, calving interval (CIN) is an indicator of female fertility that can be easily recorded. Lactation persistency (LPE; i.e., the ability of a cow to maintain a high milk yield after the lactation peak) is economically important and is related to several other traits, such as feed efficiency, health, and reproduction. The selection of these functional traits is constrained by their low heritability. In this study, variance components for CIN and LPE in the Italian Simmental cattle breed were estimated using genomic and pedigree information under the single-step genomic framework. A data set of 594,257 CIN records (from 275,399 cows) and 285,213 LPE records (from 1563,389 cows) was considered. Phenotypes were limited up to the third parity. The pedigree contained about 2 million animals, and 7,246 genotypes were available. Lactation persistency was estimated using principal component analysis on test day records, with higher values of the second extracted principal component (PC2) values associated with lower LPE, and lower PC2 values associated with higher LPE. Heritability of CIN and LPE were estimated using single-trait repeatability models. A multiple-trait analysis using CIN and production traits (milk, fat, and protein yields) was performed to estimate genetic correlations among these traits. Heritability for CIN in the single-trait model was low (0.06 $\pm 0.002)$. Unfavorable genetic correlations were found between CIN and production traits. A measure of LPE was derived using principal component analysis on test day records. The heritability and repeatability of LPE were $0.11 \pm 0.004$ and $0.20 \pm 0.02$, respectively. Ge-

Received August 7, 2019.

Accepted February 12, 2020.

*Corresponding author: acesarani@uniss.it netic correlation between CIN and LPE was weak but had a favorable direction. Despite the low heritability estimates, results of the present work suggest the possibility of including these traits in the Italian Simmental breeding program. The use of a single-step approach may provide better results for young genotyped animals without their own phenotypes.

Key words: fertility, persistency, genomic selection

\section{INTRODUCTION}

In the last century, the combined action of genetic, management, and feeding advancements has led to a substantial improvement of dairy cow performances. However, such results have been accompanied by a general deterioration in fitness traits (Sun et al., 2019). The progressive reduction of cow fertility is one of the most relevant examples of the unfavorable consequences of selection for production traits (Ma et al., 2019). Relationships between fertility and genetic improvement for milk production have been investigated (CastilloJuarez et al., 2000; Lucy, 2001; Hayes et al., 2009; Walsh et al., 2011). Reproduction traits have therefore been included in breeding programs (López-Gatius, 2003; Philipsson and Lindhé, 2003; Miglior et al., 2005) even though a clear definition of phenotypes is still an issue. For example, fertility traits can be defined in many ways: time lengths (i.e., days open) or frequencies (i.e., number of inseminations needed to conceive). Generally, these traits are difficult to record routinely and have low heritability. Among fertility traits, calving interval (CIN) is one of the easiest to record (Dal Zotto et al., 2007); however, it can be biased by not being available for cows that do not re-calve because of poor fertility. Other traits, such as conception or pregnancy rates, could be better fertility traits, but they need additional resources to be collected. A longer CIN is usually a consequence of more inseminations needed for the cow to conceive, with increased costs for the herd, and therefore is undesirable. Moreover, cows 
with longer CIN will have fewer calvings in their life. Selection for shorter CIN would increase herd profitability: more calvings per cow means more offspring that can be sold or used as replacement, decreased feed costs, and fewer reproductive problems (Esslemont et al., 2001; Groenendaal et al., 2004; Atashi et al., 2013).

Reproductive performance is also strongly related to lactation persistency ( LPE); that is, the ability of the cow to maintain high levels of production after the lactation peak (Dekkers et al., 1998). Lactation persistency is a production trait connected to health, reproduction, and feed costs (Koloi et al., 2018). The relationship between CIN and LPE in cattle has been investigated (Atashi et al., 2013; Němečková et al., 2015). Muir et al. (2004) reported a moderate, positive genetic correlation between CIN and LPE, suggesting an unfavorable and antagonistic relationship between these 2 traits. This result was confirmed by Atashi et al. (2013), who found that cows with shorter CIN were less persistent in milk production. Although there is a general consensus on the basic concept of LPE, generally defined as the ratio between the milk measured in a certain period and the total milk yield, several measurements have been proposed for this trait (Sölkner and Fuchs, 1987; Gengler, 1996; Cole and VanRaden, 2006; Strabel and Jamrozik, 2006; Togashi and Lin, 2006). Macciotta et al. (2006) have defined the LPE in Italian Simmental using a principal component (PC) approach. The advantage of this approach is that the measure of LPE is independent of milk production.

The Italian Simmental is a dual-purpose cattle breed farmed mostly in Northeastern Italy. Its breeding program aims to improve both dairy and beef traits, and an economic selection index has been developed for this purpose. Recently, the introduction of new functional traits such as CIN and LPE has been suggested; however, variance components for these traits were not available for this breed in Italy. Thus, to investigate the genetic background of these 2 traits, the present study focused on the estimation of genetic parameters for CIN and its relationship with production traits and LPE in Italian Simmental cattle using a genomic approach.

\section{MATERIALS AND METHODS}

\section{Calving Interval}

Calving interval phenotypes recorded from 275,399 cows in the period 1983 to 2017 were used. The number of parities per cow ranged from 1 to 3 , and the first record was mandatory to include a cow in the analysis. A total of 594,257 CIN records that were greater than $300 \mathrm{~d}$ and lower than $700 \mathrm{~d}$ were retained for analysis.
Heritability and repeatability for CIN were estimated using a repeatability single-trait model:

$$
\mathrm{y}=\text { hy }+ \text { par }+\mathrm{a}+\mathrm{pe}+\mathrm{e}
$$

where y was the CIN record; hy was the fixed effect of herd-year combination (103,467 levels); par was the fixed effect of parity ( 3 levels: 1 to 2,2 to 3 , or 3 to $4)$; a was the random additive genetic effect $(465,633$ animals in the relationship matrix); pe was the random effect of permanent environment (465,633 levels); and e was the random residual.

Genetic correlations between fertility and production traits were estimated using a multiple-trait animal model with the same structure as Equation [1], considering CIN and 305-d yields of milk (MY), fat, and protein $(\mathrm{kg})$. All available records for these 4 traits were included in the analysis (713,376 records from 274,759 cows). Average values $( \pm \mathrm{SD})$ of $5,687 \pm 1,676 \mathrm{~kg}, 221$ $\pm 81 \mathrm{~kg}$, and $194 \pm 70 \mathrm{~kg}$ were observed for MY, fat yield, and protein yield, respectively.

\section{Lactation Persistency}

Genetic parameters for LPE were investigated using a data set with 285,213 lactation records of 156,389 cows (parities ranging from 1 to 3 ) farmed in 5,344 herds. Each lactation (from 5 to $305 \mathrm{~d}$ in milk) was divided into 7 intervals, and 1 record per interval was kept. When more than 1 test day per interval was available, the average value was used. Seven intervals were chosen, because the majority of cows have this number of controls available in the routine evaluation system of Italian Simmental. The availability of at least 1 record before the 45th day of lactation and after the 245 th day of lactation was mandatory to include a cow in the analysis. Because milk, fat, and protein daily yields showed similar decreasing trends along lactation, we decided to consider only milk yield to define LPE. Thus, data were arranged in a multivariate framework, and a PC analysis using SAS PROC PRINCOMP (version 9.2, SAS Institute Inc., Cary, NC) was performed to extract eigenvalues and eigenvectors of the phenotypic correlation matrix of test day records. The second extracted principal component (PC2) was used as an indicator of persistency (Macciotta et al., 2006). The PC2 scores were analyzed using the following singletrait repeatability animal model:

$$
\mathrm{y}=\text { hy }+ \text { par }+\mathrm{a}+\mathrm{pe}+\mathrm{e},
$$

where y was the value of PC2 scores (i.e., LPE); hy was the combination of herd and year (49,638 levels); par 
was the effect of parity (3 levels: 1, 2, and 3); a was the random additive genetic effect (333,003 levels); pe was the random effect of permanent environment $(333,003$ levels); and e was the random residual. Finally, a 2-trait model was used to estimate genetic correlations between CIN and LPE of the corresponding lactation: CIN records between 2 consecutive parities ( 1 to 2,2 to 3 , and 3 to 4 ) and the LPE estimated for the corresponding lactations (first, second, or third lactation) were used, for a total of 340,573 records.

\section{Genetic Parameter Estimation}

Variance component and heritability $\left(\mathrm{h}^{2}\right)$ estimation for all the described models was performed using a single-step genomic REML (ssGREML) approach with a combined relationship matrix $(\mathbf{H})$ built as described in Aguilar et al. (2010). Analyses were also performed with a pedigree relationship matrix (A), with very similar results (not shown). Before the analyses, pedigree was traced back for 5 generations. The full pedigree contained 1,981,728 animals, of which 7,246 were genotyped for 40,200 markers. Among all the genotyped animals, 3,358 were females with phenotypes, and 2,045 were sires. The females with both phenotypes and genotypes came from 250 different herds and could be dams of other phenotyped females. The other genotyped animals without phenotypes were half-sibs or relatives of phenotyped females. Table 1 shows the distribution of genotyped animals by year of birth. Variance components were estimated using the average information REML (AIREML) algorithm implemented in the blupf90 family programs (Misztal et al., 2014).

Table 1. Distribution of genotyped animals by birth year

\begin{tabular}{lc}
\hline Year of birth & Animals (no.) \\
\hline 1963 to 1980 & 38 \\
1981 to 1990 & 245 \\
1991 to 2000 & 816 \\
2001 & 118 \\
2002 & 126 \\
2003 & 148 \\
2004 & 196 \\
2005 & 179 \\
2006 & 169 \\
2007 & 196 \\
2008 & 238 \\
2009 & 269 \\
2010 & 318 \\
2011 & 336 \\
2012 & 427 \\
2013 & 859 \\
2014 & 1,048 \\
2016 & 790 \\
2017 & 389 \\
2018 & 265 \\
\hline
\end{tabular}

\section{RESULTS AND DISCUSSION}

\section{Calving Interval in a Single-Trait Repeatability Model}

The phenotypic average of CIN for Italian Simmental $(397.50 \pm 68.32)$ is consistent with previous reports on other cattle breeds. Values between 387 and 398 were reported for UK Holsteins (Wall et al., 2003) and Australian Holsteins (Haile-Mariam et al., 2003), respectively. Calving intervals of $400 \mathrm{~d}$ or more were found in Spanish dairy cattle (González-Recio and Alenda, 2005) and in Mexican Holsteins (Montaldo et al., 2010). Large values of CIN were also reported for US Holsteins (Tiezzi et al., 2017).

Heritability $(0.06 \pm 0.002)$ and repeatability $(0.11$ \pm 0.002 ) for CIN in the present study, using a singletrait model, were quite low. However, they were slightly higher than previous literature reports. Values of 0.02 were estimated in Mexican Holsteins (Montaldo et al., 2010) and in Xinjiang Browns (Fu et al., 2017). Estimates ranging from 0.03 to 0.05 were reported for Australian dairy cattle (Haile-Mariam et al., 2003, 2008), UK Holsteins (Wall et al., 2003), Irish Holsteins (Olori et al., 2002), Spanish dairy cattle (González-Recio and Alenda, 2005), and Italian Brown Swiss cattle (Dal Zotto et al., 2007). It should be noted that heritability for fertility traits is generally low, as reported in a recent review (Ma et al., 2019).

\section{Lactation Persistency}

About $90 \%$ of the total phenotypic variance of test day records was explained by the first $2 \mathrm{PC}$. The first PC (PC1) was related to the average level of milk yield, whereas PC2 was associated with the shape of the lactation curve. They explained about $78 \%$ and $12 \%$ of test day phenotypic variance, respectively. The $\mathrm{PC} 1$ scores ranged from -7.60 to 14.54 , with an average value of $0.14 \pm 2.37$, and showed a correlation of 0.97 with 305-d MY. Scores for PC2 ranged from -4.53 to 4.71. Animals were grouped according to their $\mathrm{PC} 2$ scores into 4 classes: class $1=-4.53$ to -1.04 ; class 2 $=-1.03$ to -0.57 ; class $3=-0.56$ to -0.15 ; and class $4=-0.14$ to 4.71 . Average milk yield for all 7 test day records were calculated separately for each PC2 class. These average lactation curves for different PC2 classes are shown in Figure 1. It can be clearly seen that the average lactation curve for PC2 class 4 exhibited the steepest negative slope. The LPE tends to increase for higher $\mathrm{PC} 2$ classes, reaching the maximum in class 1. These results confirm the meaning of $\mathrm{PC} 2$ score as an indicator of the shape of the lactation curve.

The second PC (i.e., LPE) and MY showed a phenotypic correlation of -0.03 , which was expected because 
PC2 was defined to be independent of milk production in the calculations. However, the genetic correlation between PC2 and MY was unfavorable $(0.35 \pm 0.03)$ because higher values of PC2 - that is, lower LPE - are associated with higher MY. In fact, animals belonging to class 1 (those with the highest LPE) showed a slightly lower 305-d MY compared with the animals of class 4 (those with the lowest LPE). The LPE in this study was not defined by combining production levels at different lactation stages, but by using the $\mathrm{PC} 2$ values that just capture the shape of lactation curve, without considering production levels (PC are orthogonal). Thus, the genetic correlation observed between LPE and MY are likely a spurious result mediated by other variables. In the literature, estimates of genetic correlation between LPE and MY show different magnitudes and signs according to the LPE definition (Haile Mariam et al., 2003; Muir et al., 2004). Cole and Null (2009) found that genetic correlation between LPE and MY changed magnitudes and signs according to the considered breed. Some studies reported unfavorable genetic correlation between LPE and MY (Cobuci

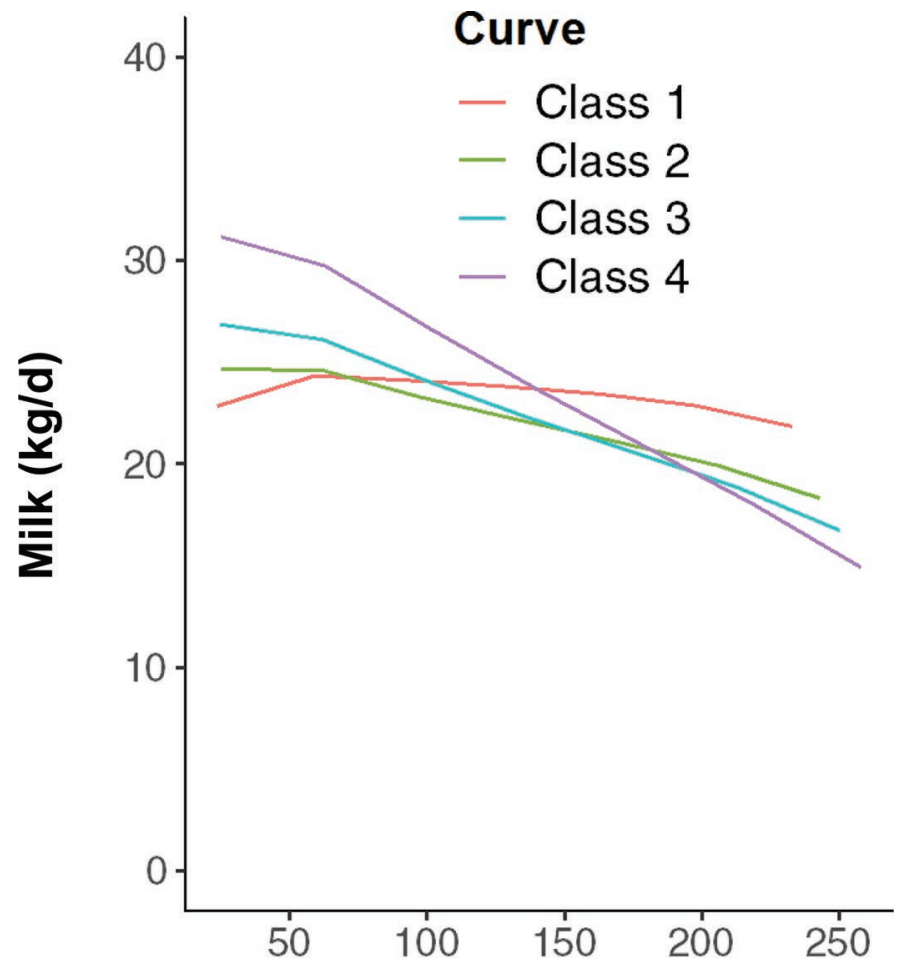

Days in Milk

Figure 1. Average shape of the lactation curve using quartiles of the second principal component (PC2), associated with lactation persistency. Each curve is made using the average value of milk production (kilograms per day) of all animals belonging to the first (class 1), second (class 2), third (class 3), and fourth (class 4) quartiles of PC2. and Costa, 2012; Khorshidie et al., 2012; Pereira et al., 2012), whereas other studies reported favorable genetic correlation between these 2 traits (Muir et al., 2004; Yamazaki et al., 2013).

Heritability $(0.11 \pm 0.004)$ and repeatability $(0.20 \pm$ $0.003)$ of LPE in a single-trait model were rather low. Macciotta et al. (2006) reported lower heritability and repeatability for LPE using a smaller, older data set that comprised only phenotypic and pedigree information from the same Italian Simmental population. In fact, heritability estimates for LPE in the literature exhibit considerable variation, with values ranging from 0.01 (Otwinowska-Mindur and Ptak, 2015) to 0.50 (Koloi et al., 2018). Such relevant differences can be ascribed to statistical model, breed, and trait definition. No consensus currently exists in the literature for measuring LPE. Grayaa et al. (2019) defined LPE as the difference between milk production at 280 DIM and at the lactation peak, and estimated heritability using different multi-trait models; the estimates ranged from 0.05, when milk fat percentage was considered, to 0.21 when MY was included among the response variables. Strabel and Jamrozik (2006) reported heritability estimates for LPE that ranged from 0.07 to 018 using the eigenvectors of the variance or covariance matrices of RRM coefficients. Higher heritability $(0.18 \pm 0.02)$ was reported for LPE for first-lactation Canadian Holsteins (Muir et al., 2004). Additionally, Cole and Null (2009) observed large heterogeneity in the $\mathrm{h}^{2}$ of LPE in several dairy cattle breeds: from 0.09 to 0.26 and 0.18 to 0.28 for Milking Shorthorn and Guernsey cattle, respectively.

\section{Calving Interval, Production Traits, and Lactation Persistency}

Heritability for CIN obtained with the multiple-trait model was slightly higher compared with the singletrait analysis (Table 2). Heritabilities for production traits were close to the current estimates for the Italian Simmental breed. Unfavorable, moderate genetic correlations were found between CIN and production traits (Table 2), as generally reported in literature. The magnitude of the estimates obtained in the present study is not far from previous reports of about 0.5 to 0.6 (Pryce et al., 2000; Dal Zotto et al., 2007; Fu et al., 2017). Deb et al. (2008) reported a genetic correlation of 0.4 between CIN and MY in a native breed from Bangladesh. Antagonistic genetic correlation between MY and CIN was also observed by Haile-Mariam et al. (2003) and by Strapáková et al. (2016). Strapáková et al. (2016) reported a genetic correlation of $0.51 \pm 0.11$, with higher MY observed for cows with longer calving interval. Other similar reproductive traits, such as 
Table 2. Heritability (diagonal), phenotypic (above diagonal), and genetic (below diagonal) correlations for calving interval and production traits using a 4-trait model

\begin{tabular}{lcccc}
\hline Item & Calving interval & Milk yield & Fat yield & Protein yield \\
\hline Calving interval & $0.09 \pm 0.02$ & 0.17 & 0.15 & 0.16 \\
Milk yield & $0.64 \pm 0.02$ & $0.26 \pm 0.02$ & 0.88 & 0.96 \\
Fat yield & $0.63 \pm 0.02$ & $0.86 \pm 0.01$ & $0.25 \pm 0.02$ & 0.89 \\
Protein yield & $0.56 \pm 0.02$ & $0.95 \pm 0.01$ & $0.90 \pm 0.01$ & $0.22 \pm 0.02$ \\
\hline
\end{tabular}

days open and days from calving to first service, show undesirable genetic correlations with milk production traits (Abe et al., 2009).

Heritability estimates for CIN and LPE using the univariate or bivariate models were similar. A weak, positive genetic correlation was observed between these 2 traits, whereas a phenotypic correlation near 0 was observed (Table 3). The positive genetic correlation reflected a favorable association between CIN and LPE because high values of CIN are associated with high values of $\mathrm{PC} 2$, which means lower LPE. On the contrary, lower values of CIN (desirable) are related to lower values of PC2 and, therefore, to higher LPE (desirable). However, reports about the genetic association between CIN and LPE are not always consistent. An undesirable association between CIN and LPE was reported by Atashi et al. (2013), who found that cows with short CIN had lower LPE. Unfavorable genetic correlation between CIN and LPE was also reported by Muir et al. (2004). Němečková et al. (2015) reported no significant association between these 2 traits, and Andersen et al. (2011) found no significant differences in peak yield and peak day (i.e., traits associated with LPE) among different CIN groups. Haile-Mariam et al. (2003) concluded that the genetic correlation between LPE and CIN was almost 0. Apart from sampling effect, it should be pointed out that the different definition of LPE used in the various studies may strongly affect the results.

An antagonistic relationship between productive and reproductive performances in cattle has been observed: animals need energy to simultaneously produce milk and conceive, and, therefore, the energy balance during lactation is of great interest. However, fertility and production traits are associated in a complex causal pattern because this relationship strongly depends on the considered period of the lactation. Attention can be focused mainly on energy balance during lactation: MY affects energy balance mostly in the first part of the lactation, when cows are inseminated; in this period, body reserve mobilization and negative energy balance frequently occur, and the cow has insufficient energy to conceive (Collard et al., 2000; Andersen et al., 2011). Thus, a high level of milk production in early lactation (before or around the peak) could reduce fertility, with a subsequent delay of pregnancy. In late lactation, a change in the causal link between productive and reproductive performance occurs: in this period, energy requirements for fetal development are higher than in the first part of lactation, and, therefore, pregnancy prioritizes energy needs, with an effect on milk production (milk production in the late stages can be identified as LPE). More persistent cows with lower peak yield usually suffer a less strong energy imbalance during the lactation (Haile-Mariam et al., 2003). The results of the present study highlight quite a strong unfavorable genetic correlation between CIN and MY, confirming the negative relationship between reproductive and productive performance. A slightly favorable genetic correlation between LPE and CIN was also observed. However, such a relationship between LPE and CIN could be influenced by MY, because selection for CIN is unlikely to cause decline in MY, but selection for MY ignoring CIN would have more negative effects on fertility due to the high unfavorable genetic correlation between these 2 traits. Nevertheless, LPE has some positive consequences for dairy cows, because persistent cows may have fewer health and reproduction problems, they are easier to manage, and they have lower feeding costs (Sölkner and Fuchs, 1987; Atashi et al., 2013). Thus, the findings of the present work suggest the possibility of limiting the fertility deterioration

Table 3. Heritability, repeatability, and correlations (phenotypic and genetic) for calving interval and lactation persistency using the 2-trait model

\begin{tabular}{lcccc}
\hline & & \multicolumn{2}{c}{ Correlation } \\
\cline { 3 - 4 } Item & Heritability & Repeatability & Phenotypic & Genetic \\
\hline Calving interval & $0.05 \pm 0.01$ & $0.11 \pm 0.01$ & -0.05 & $0.25 \pm 0.03$ \\
Lactation persistency & $0.11 \pm 0.01$ & $0.20 \pm 0.01$ & & \\
\hline
\end{tabular}


caused by selection for MY by including CIN and LPE as breeding goals.

In spite of the low $\mathrm{h}^{2}$ for CIN and LPE that has been confirmed in the present study, it should be pointed out that genomic selection offers interesting perspectives for improving these functional traits, if more phenotypes and genotypes are collected. García-Ruiz et al. (2016) showed that the genetic gain per year achieved in US Holsteins has been markedly larger for low heritability traits because of the considerable amount of data (e.g., SCS, productive life, and daughter pregnancy rate). In estimating variance components, the main benefit of using genomic information in a single-step approach is the availability of more data, which is reflected in smaller standard errors (Forni et al., 2011; Veerkamp et al., 2011). The use of combined pedigree and genomic information using the single-step approach could have benefits for young candidates that have genotypes but no phenotypic records. However, in our case, using $\mathbf{A}$ instead of $\mathbf{H}$ gave very close estimates (data not shown) because of the small number of genotyped animals. The similar results found using BLUP or single-step genomic BLUP, even with a small number of genotyped animals, showed the robustness of the latter methodology and the possibility of obtaining better results by increasing the amount of genomic information.

\section{CONCLUSIONS}

Although of small magnitude, the heritabilities for CIN and LPE show that these traits can be improved via genomic selection. The use of multi-trait models allowed better understanding of the genetic connection between CIN and LPE, showing that both traits should be included as breeding objectives, to prevent deterioration of fertility.

\section{ACKNOWLEDGMENTS}

This work was supported by the Italian government (Associazione Nazionale Allevatori Pezzata Rossa Italiana) through the project Dual Breeding-Le razze bovine a duplice attitudine: Un modello alternativo di Zootecnia eco-sostenibile (Dual purpose cattle breeds: an eco-sustainable option for the animal husbandry; grant no. J21J18000010005). The authors declare that they have no conflicts of interest.

\section{REFERENCES}

Abe, H., Y. Masuda, and M. Suzuki. 2009. Relationships between reproductive traits of heifers and cows and yield traits for Holsteins in Japan. J. Dairy Sci. 92:4055-4062. https://doi.org/10.3168/jds .2008-1896.
Aguilar, I., I. Misztal, D. L. Johnson, A. Legarra, S. Tsuruta, and T. J. Lawlor. 2010. Hot topic: A unified approach to utilize phenotypic, full pedigree, and genomic information for genetic evaluation of Holstein final score. J. Dairy Sci. 93:743-752. https://doi.org/10 $.3168 /$ jds.2009-2730.

Andersen, F., O. Østerås, O. Reksen, N. Toft, and Y. T. Gröhn. 2011. Associations between the time of conception and the shape of the lactation curve in early lactation in Norwegian dairy cattle. Acta Vet. Scand. 53:5. https://doi.org/10.1186/1751-0147-53-5.

Atashi, H., M. J. Zamiri, A. Akhlaghi, M. Dadpasand, M. B. Sayyadnejad, and A. R. Abdolmohammadi. 2013. Association between the lactation curve shape and calving interval in Holstein dairy cows of Iran. Majallah-i Tahqiqat-i Dampizishki-i Iran 14:88-93.

Castillo-Juarez, H., P. A. Oltenacu, R. W. Blake, C. E. McCulloch, and E. G. Cienfuegos-Rivas. 2000. Effect of herd environment on the genetic and phenotypic relationships among milk yield, conception rate, and somatic cell score in Holstein cattle. J. Dairy Sci. 83:807-814. https://doi.org/10.3168/jds.S0022-0302(00)74943-5.

Cobuci, J. A., and C. N. Costa. 2012. Persistency of lactation using random regression models and different fixed regression modeling approaches. Rev. Bras. Zootec. 41:1996-2004. https://doi.org/10 $.1590 /$ S1516-35982012000900005.

Cole, J. B., and D. J. Null. 2009. Genetic evaluation of lactation persistency for five breeds of dairy cattle. J. Dairy Sci. 92:2248-2258. https://doi.org/10.3168/jds.2008-1825.

Cole, J. B., and P. M. VanRaden. 2006. Genetic evaluation and best prediction of lactation persistency. J. Dairy Sci. 89:2722-2728. https://doi.org/10.3168/jds.S0022-0302(06)72348-7.

Collard, B. L., P. J. Boettcher, J. M. Dekkers, D. Petitclerc, and L. R. Schaeffer. 2000. Relationships between energy balance and health traits of dairy cattle in early lactation. J. Dairy Sci. 83:2683-2690.

Dal Zotto, R., M. De Marchi, C. Dalvit, M. Cassandro, L. Gallo, P. Carnier, and G. Bittante. 2007. Heritabilities and genetic correlations of body condition score and calving interval with yield, somatic cell score, and linear type traits in Brown Swiss cattle. J. Dairy Sci. 90:5737-5743. https://doi.org/10.3168/jds.2007-0280.

Deb, G. K., M. M. Mufti, M. P. Mostari, and K. S. Huque. 2008. Genetic evaluation of Bangladesh livestock research institute cattle breed-1: Heritability and genetic correlation. Bangladesh J. Anim. Sci. 37:25-33. https://doi.org/10.3329/bjas.v37i2.9878.

Dekkers, J. C. M., J. H. Ten Hag, and A. Weersink. 1998. Economic aspects of persistency of lactation in dairy cattle. Livest. Prod. Sci. 53:237-252. https://doi.org/10.1016/S0301-6226(97)00124-3.

Esslemont, R. J., Kossaibati, M. A., and J. Allcock, J. 2001. Economics of fertility in dairy cows. British Society of Animal Science Occasional Publication, 26:19-29.

Forni, S., I. Aguilar, and I. Misztal. 2011. Different genomic relationship matrices for single-step analysis using phenotypic, pedigree and genomic information. Genet. Sel. Evol. 43:1. https://doi.org/ 10.1186/1297-9686-43-1.

Fu, X., L. Lu, X. Huang, Y. Wang, K. Tian, X. Xu, J. Fang, L. Cheng, Z. Guo, and Y. Tian. 2017. Estimation of genetic parameters for 305 days milk yields and calving interval in Xinjiang Brown cattle. Agric. Sci. 8:46-55. https://doi.org/10.4236/as.2017.81004.

García-Ruiz, A., J. B. Cole, P. M. VanRaden, G. R. Wiggans, F. J. Ruiz-López, and C. P. Van Tassell. 2016. Changes in genetic selection differentials and generation intervals in US Holstein dairy cattle as a result of genomic selection. Proc. Natl. Acad. Sci. USA 113:E3995-E4004. https://doi.org/10.1073/pnas.1519061113.

Gengler, N. 1996. Persistency of lactation yields: A review. Interbull Bull. 12:87-96.

González-Recio, O., and R. Alenda. 2005. Genetic parameters for female fertility traits and a fertility index in Spanish dairy cattle. J. Dairy Sci. 88:3282-3289. https://doi.org/10.3168/jds.S0022 $-0302(05) 73011-3$

Grayaa, M., S. Vanderick, B. Rekik, A. Ben Gara, C. Hanzen, S. Grayaa, R. Reis Mota, H. Hammami, and N. Gengler. 2019. Linking first lactation survival to milk yield and components and lactation persistency in Tunisian Holstein cows. Arch. Anim. Breed 62:153-160. https://doi.org/10.5194/aab-62-153-2019. 
Groenendaal, H., D. T. Galligan, and H. A. Mulder. 2004. An economic spreadsheet model to determine optimal breeding and replacement decisions for dairy cattle. J. Dairy Sci. 87:2146-2157. https:/ /doi.org/10.3168/jds.S0022-0302(04)70034-X.

Haile-Mariam, M., P. J. Bowman, and M. E. Goddard. 2003. Genetic and environmental relationship among calving interval, survival, persistency of milk yield and somatic cell count in dairy cattle. Livest. Prod. Sci. 80:189-200. https://doi.org/10.1016/S0301 -6226(02)00188-4.

Haile-Mariam, M., M. J. Carrick, and M. E. Goddard. 2008. Genotype by environment interaction for fertility, survival, and milk production traits in Australian dairy cattle. J. Dairy Sci. 91:4840-4853. https://doi.org/10.3168/jds.2008-1084.

Hayes, B. J., P. J. Bowman, A. J. Chamberlain, and M. E. Goddard. 2009. Invited review: Genomic selection in dairy cattle: Progress and challenges. J. Dairy Sci. 92:433-443. https://doi.org/10.3168/ jds.2008-1646.

Khorshidie, R., A. A. Shadparvar, N. G. Hossein-Zadeh, and S. J. Shakalgurabi. 2012. Genetic trends for 305-day milk yield and persistency in Iranian Holsteins. Livest. Sci. 144:211-217. https://doi .org/10.1016/j.livsci.2011.11.016.

Koloi, S., K. Pathak, M. Karunakaran, and A. Mandal. 2018. Lactation persistency and its genetic evaluation in cattle-A review. Research and Reviews: J. Dairy Sci. Technol. 7:1-8.

López-Gatius, F. 2003. Is fertility declining in dairy cattle? A retrospective study in northeastern Spain. Theriogenology 60:89-99. https://doi.org/10.1016/S0093-691X(02)01359-6.

Lucy, M. C. 2001. Reproductive loss in high-producing dairy cattle: Where will it end? J. Dairy Sci. 84:1277-1293. https://doi.org/10 .3168/jds.S0022-0302(01)70158-0.

Ma, L., J. B. Cole, Y. Da, and P. M. VanRaden. 2019. Symposium review: Genetics, genome-wide association study, and genetic improvement of dairy fertility traits. J. Dairy Sci. 102:3735-3743. https://doi.org/10.3168/jds.2018-15269.

Macciotta, N. P. P., D. Vicario, and A. Cappio-Borlino. 2006. Use of multivariate analysis to extract latent variables related to level of production and lactation persistency in dairy cattle. J. Dairy Sci. 89:3188-3194. https://doi.org/10.3168/jds.S0022-0302(06)72593 -0 .

Miglior, F., B. L. Muir, and B. J. Van Doormaal. 2005. Selection indices in Holstein cattle of various countries. J. Dairy Sci. 88:12551263. https://doi.org/10.3168/jds.S0022-0302(05)72792-2.

Misztal, I., S. Tsuruta, D. Lourenco, I. Aguilar, A. Legarra, and Z. Vitezica. 2014. Manual for BLUPF90 family of programs. Accessed Jan. 2019. http://nce.ads.uga.edu/wiki/lib/exe/fetch.php?media =blupf90_all7.pdf.

Montaldo, H. H., H. Castillo-Juárez, M. Valencia-Posadas, E. G. Cienfuegos-Rivas, and F. J. Ruiz-López. 2010. Genetic and environmental parameters for milk production, udder health, and fertility traits in Mexican Holstein cows. J. Dairy Sci. 93:2168-2175. https: //doi.org/10.3168/jds.2009-2050.

Muir, B. L., J. Fatehi, and L. R. Schaeffer. 2004. Genetic relationships between persistency and reproductive performance in firstlactation Canadian Holsteins. J. Dairy Sci. 87:3029-3037. https:// doi.org/10.3168/jds.S0022-0302(04)73435-9.

Němečková, D., L. Stádník, and J. Čítek. 2015. Associations between milk production level, calving interval length, lactation curve parameters and economic results in Holstein cows. Mljekarstvo: časopis za unaprjeđenje proizvodnje i prerade mlijeka 65:243-250.

Olori, V. E., T. H. E. Meuwissen, and R. F. Veerkamp. 2002. Calving interval and survival breeding values as measure of cow fertility in a pasture-based production system with seasonal calving. J. Dairy Sci. 85:689-696. https://doi.org/10.3168/jds.S0022-0302(02)74125 -8 .

Otwinowska-Mindur, A., and E. Ptak. 2015. Genetic analysis of lactation persistency in the Polish Holstein-Friesian cows. Anim. Sci. Pap. Rep. 33:2.
Pereira, R. J., R. S. Verneque, P. S. Lopes, M. L. Santana Jr., M. R. Lagrotta, R. A. Torres, A. E. Vercesi Filho, and M. A. Machado. 2012. Milk yield persistency in Brazilian Gyr cattle based on a random regression model. Genet. Mol. Res. 11:1599-1609. https:/ /doi.org/10.4238/2012.June.15.9.

Philipsson, J., and B. Lindhé. 2003. Experiences of including reproduction and health traits in Scandinavian dairy cattle breeding programmes. Livest. Prod. Sci. 83:99-112. https://doi.org/10.1016/ S0301-6226(03)00047-2.

Pryce, J. E., M. P. Coffey, and S. Brotherstone. 2000. The genetic relationship between calving interval, body condition score and linear type and management traits in registered Holsteins. J. Dairy Sci. 83:2664-2671. https://doi.org/10.3168/jds.S0022-0302(00)75160 -5 .

Sölkner, J., and W. Fuchs. 1987. A comparison of different measures of persistency with special respect to variation of test-day milk yields. Livest. Prod. Sci. 16:305-319. https://doi.org/10.1016/0301 -6226(87)90001-7.

Strabel, T., and J. Jamrozik. 2006. Alternative measures of lactation persistency from random regression models with Legendre polynomials. Pages 1-33 in Proc. 8th World Congress on Genetics Applied to Livestock Production, Belo Horizonte, Minas Gerais, Brazil. Instituto Prociência, Belo Horizonte, Brazil.

Strapáková, E., J. Candrák, and P. Strapák. 2016. Genetic relationship of lactation persistency with milk yield, somatic cell score, reproductive traits, and longevity in Slovak Holstein cattle. Arch. Tierzucht 59:329-335. https://doi.org/10.5194/aab-59-329-2016.

Sun, H. Z., G. Plastow, and L. L. Guan. 2019. Invited review: Advances and challenges in application of feedomics to improve dairy cow production and health. J. Dairy Sci. 102:5853-5870. https:// doi.org/10.3168/jds.2018-16126.

Tiezzi, F., G. de Los Campos, K. L. Parker Gaddis, and C. Maltecca. 2017. Genotype by environment (climate) interaction improves genomic prediction for production traits in US Holstein cattle. J. Dairy Sci. 100:2042-2056. https://doi.org/10.3168/jds.2016-11543.

Togashi, K., and C. Y. Lin. 2006. Selection for milk production and persistency using eigenvectors of the random regression coefficient matrix. J. Dairy Sci. 89:4866-4873. https://doi.org/10.3168/jds .S0022-0302(06)72535-8.

Veerkamp, R. F., H. A. Mulder, R. Thompson, and M. P. L. Calus 2011. Genomic and pedigree-based genetic parameters for scarcely recorded traits when some animals are genotyped. J. Dairy Sci. 94:4189-4197. https://doi.org/10.3168/jds.2011-4223.

Wall, E., S. Brotherstone, J. A. Woolliams, G. Banos, and M. P. Coffey. 2003. Genetic evaluation of fertility using direct and correlated traits. J. Dairy Sci. 86:4093-4102. https://doi.org/10.3168/ jds.S0022-0302(03)74023-5.

Walsh, S. W., E. J. Williams, and A. C. O. Evans. 2011. A review of the causes of poor fertility in high milk producing dairy cows. Anim. Reprod. Sci. 123:127-138. https://doi.org/10.1016/j .anireprosci.2010.12.001.

Yamazaki, T., K. Hagiya, H. Takeda, O. Sasaki, S. Yamaguchi, M. Sogabe, Y. Saito, S. Nakagawa, K. Togashi, K. Suzuki, and Y. Nagamine. 2013. Genetic correlations between milk production traits and somatic cell scores on test day within and across first and second lactations in Holstein cows. Livest. Sci. 152:120-126. https://doi.org/10.1016/j.livsci.2012.12.015.

\section{ORCIDS}

Alberto Cesarani $\odot$ https://orcid.org/0000-0003-4637-8669 Giustino Gaspa ๑ https://orcid.org/0000-0003-1604-8917 Yutaka Masuda (ㄴ) https://orcid.org/0000-0002-3428-6284 Daniela A. L. Lourenco (1) https://orcid.org/0000-0003-3140-1002 Nicolò P. P. Macciotta @ https://orcid.org/0000-0001-5504-9459 